\title{
Modern Treatment of Acute Myocardial Infarction with ST-segment Elevation Complicated with Out-of-Hospital Cardiac Arrest
}

\author{
Ratko Lasica ${ }^{1}$, Mina Radosavljevic-Radovanovic ${ }^{1}$, Predrag Mitrovic ${ }^{1}$, Ana Uscumlic ${ }^{1}$, Igor \\ Mrdovic ${ }^{1}$, Milan Nedeljkovic ${ }^{2}$, Branislav Stefanovic ${ }^{1}$, Vladimir Zobenica ${ }^{1}$, Milika Asanin ${ }^{1}$ \\ ${ }^{1}$ Emergency Hospital, Clinical Center of Serbia, Belgrade, Serbia, ${ }^{2}$ Cardiology Clinic, Clinical Center of Serbia, \\ Belgrade, Serbia
}

Abstract

Background: The most common cause of early death in acute myocardial infarction with ST elevation are malignant heart rhythm disorders, generally occurring in the first four hours of myocardial infarction. The incidence of ventricular fibrillation is greatest in the early stage of the myocardial infarction, and sudden cardiac deaths occur most often in outpatient conditions.

Case reports: This paper presents a patient whose first manifestation of coronary artery disease was myocardial infarction with ST elevation complicated by early ventricular fibrillation. Rapid measures of cardiopulmonal resuscitation enabled quick establishment of normal sinus rhythm. Primary percutaneous intervention was performed, with revascularization of artery responsible for acute myocardial infarction. In order to reduce ischemic brain damage, therapeutic hypothermia was applied since the patient was presented in post-reanimation coma.

Conclusion: Better treatment of patients with cardiac arrest in outpatient conditions and faster revascularization of the infarct artery are crucial for a reduction of mortality in acute myocardial infarction.

Key words acute myocardial infarction, cardiac arrest, modern treatment

\section{Background}

$\mathrm{n}$ spite of significant progress in both diagnosis and therapy, intrahospital mortality of ST segment myocardial infarction (STEMI) is still significantly high (between $4 \%$ and $12 \%$ ), while one-year mortality in angiographic registries is $10 \%{ }^{1}$ Ventricular fibrillation (VF) is still the most frequent cause of sudden death in patients with STEMI, occurring in $80 \%$ of all VF in the first four hours of myocardial infarction. ${ }^{2}$ Since this arrhythmia early ocurrs most commonly in the course of myocardial infarction, sudden deaths usually happen out of hospital. Fast defibrillation is the main determinant of survival in patients with VF and urgent coronary angiography with primary percutaneous intervention $(\mathrm{pPCl})$ is the treatment of choice in patients with cardiac arrest in the course of STEMI. ${ }^{3}$ If there are no contraindications, therapeutic hypothermia is indicated in early phase after resuscitation in patients in postreanimation coma. ${ }^{4-6}$

\section{Case report}

We present a male patient aged 37 who experienced the out-of-hospital syncopa on the day of admission to the Emergency Hospital of the Clinical Center of Serbia. He was not injured since his was held by his wife standing by his side. Patient's wife started external cardiac massage and since Emergency Medical Service arrived and did not register pulsees on big body arteries, cardiopulmonal resuscitation was continued. Electrocardiogram had shown VF which was terminated with an asynchrone DC shock. After the cardiac rhythm was established, electrocardiogram showed anterolateral STEMI and the patient was referred to Emergency Hospital and then admitted to the Urgent Cardiology Department of the Clinical Center of Serbia.

On admission, the patient was unconscious, intubated, insufficiently breathing, afebrile, acyanotic. He was in sinus rhythm, tachycardia was observed, with gallop rhythm and third heart sound. Normal breathing sound was registered. He was hypertensive (160/100 $\mathrm{mmHg}$ ) and tachycardic (Heart rate: $110 / \mathrm{min}$ ). Admission electrocardiogram had shown wider QRS complexes with right brunch block and ST segment elevation in anterolateral lead series. (Figure 1.)

Shortly after admission a nasogastric probe was placed and loading doses of Acetylsalycilic acid $(300 \mathrm{mg})$ and Ticagrelor $(180 \mathrm{mg})$ were administered. Since the patient was in cardiac arrest and resuscitated, his bleed- 

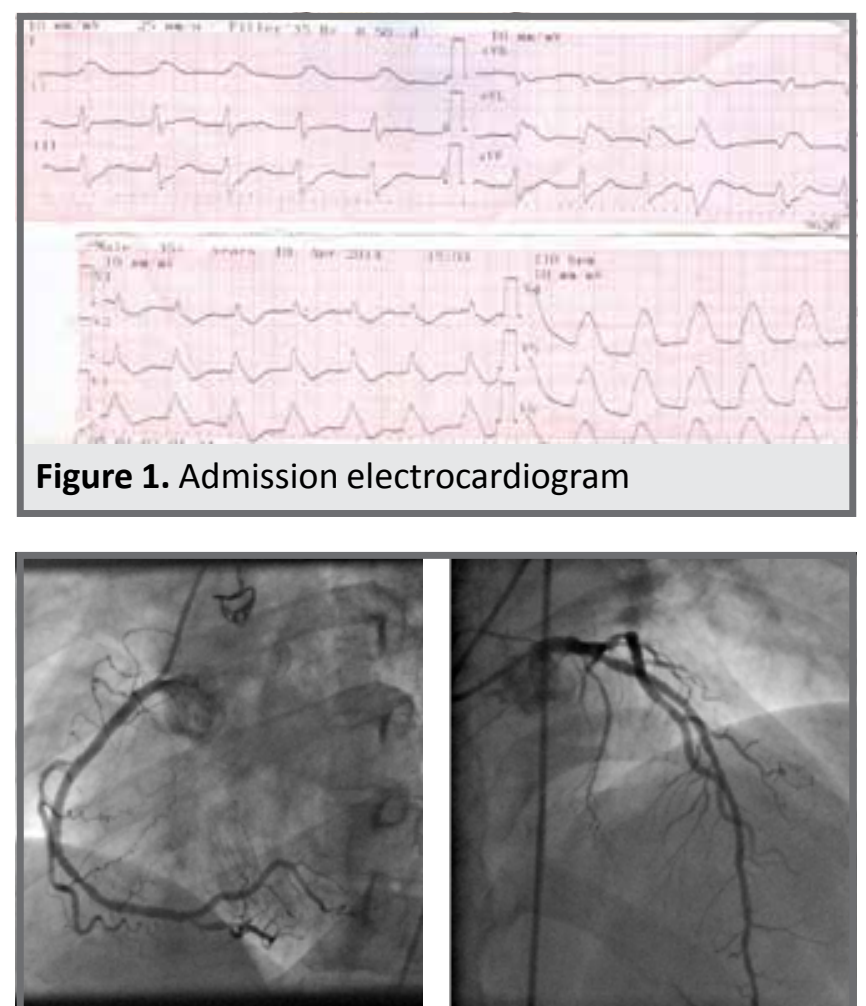

PLD-KA

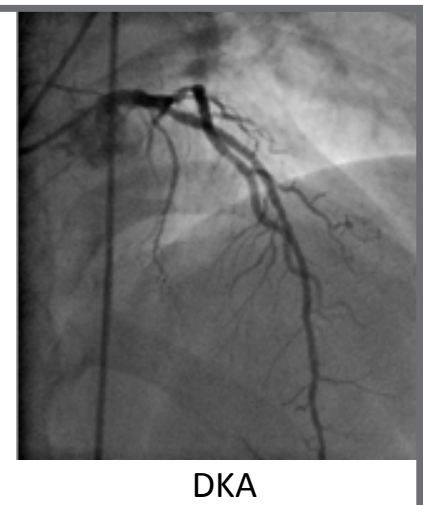

Figure 3. $L A D$ and RCA after revascularization

ing risk was high and Pantoprasol was administered through nasogastric probe. Due to agitation and insufficient breathing, sedation with Propofol and Midasolam was administered and assisted mechanical ventilation was performed. The patient was urgently transfered to the catheterisation laboratory for coronary angiography and $\mathrm{pPCl}$.

Coronary angiography revealed a two-vessel coronary artery disease. An occlusive lesion in the medial segment of left descendent coronary artery (LAD) spreading to the first diagonal brunch was observed along with two significant stenoses in medial and distal segments of the right coronary artery (RCA) (Figure 2). Revascularisation of LAD with implantation of two drug eluting stents in LAD was performed (drug-eluting stentDES). Tranzienr hypotension was registered in cath lab, so revascularisarion of RCA was performed with implantation of two DES (Figure 3.). Electrocardiogram after revascularization had shown a resolution of ST segment elevation in anterolateral lead series, with loss of right brunch block. (Figure 4).

Upon arrival from catheterization laboratory the patient was still unconscious, on assisted mechanical ventilation, normotensive $(110 / 70 \mathrm{mmHg})$. Laboratory analysis showed increased values of markers of cardiac necrosis (CK 1017 IU/L; Tn I 0.9 ng/ml), increased values of total cholesterol and disturbed fraction of cholesterols (Holesterol - 6.34; HDL holesterol 0.94, LDL holesterol $4.68 \mathrm{mmol} / \mathrm{L})$. Echocardiogram had shown the left ventricle normal in size and shape (EDD/ESD- 52/37 $\mathrm{mm}$ ). The analysis of regional kinetics revealed hypokinesis of left ventricle apex and ejection fraction measured according to Simpson was approximately $50 \%$.

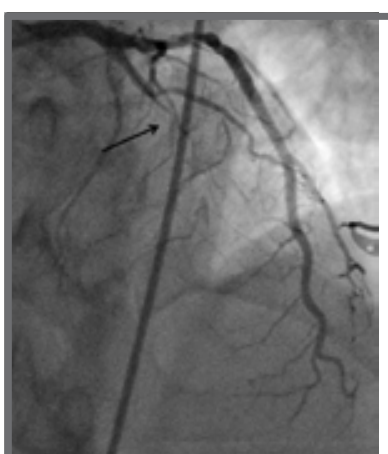

PLD-KA

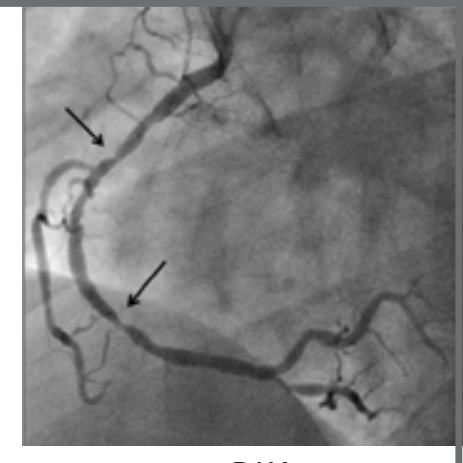

DKA
Figure 2. LAD and RCA before revascularisation

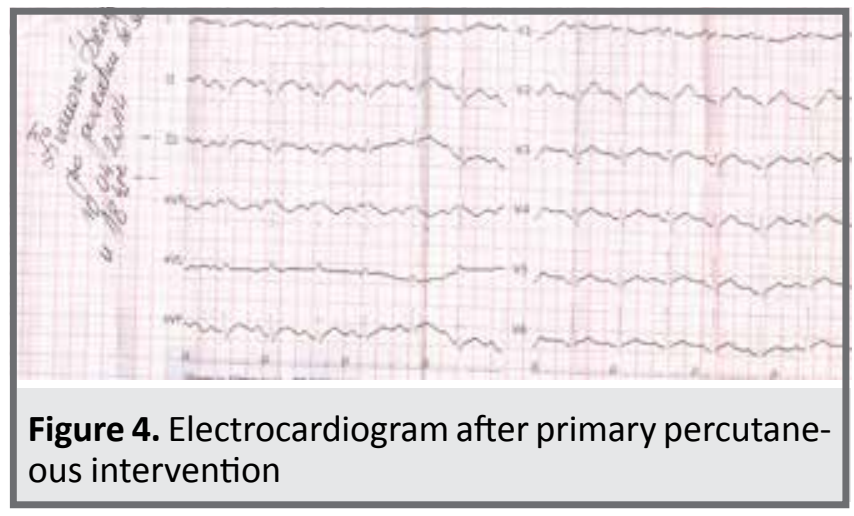

Neurologic examination was performed along with endocranial CT, and after exclusion of contrainidications therapeutic hypothermia was initiated and continued during next 24 hours followed by constant hemodynamic and laboratory monitoring. After 24 hours of therapeutic hypothermia gradual rewarming was initiated, intravenous sedation (started before hypothermia) was stopped; then the patient became conscious. He was extubated and stable throughout hospitalization. He was discharged to outpatient treatment with double antiplatelet therapy (Acetyl salicylic acid $100 \mathrm{mg}$ and Ticagrelor 2x90 mg), beta blocker, ACE inhibitor and Rosuvastatin.

On follow-up, the patient was asymptomatic, with high tolerance for physical efforts. A new echocardiogram showed no disturbances in regional kinetics.

\section{Discussion}

Considering that STEMI in our patient was complicated with out-of-hospital cardiac arrest it is clear that improvement of pre-hospital care of STEMI patients is crucial for their better survival. According to the latest recommendations for STEMI published in 2017, it is evident that all medical professionals should be trained and familiar with the use of defibrillators and be able to maintain vital functions, which was the case with our patient. Fast defibrillation is the main determinant of survival in patients with VF. If cardiopulmonary resuscitation measures are applied in patients with VF and DC shock is applied in the first four minutes, the survival rate is up to $30 \%$, while in patients in whom cardiopulmonary resuscitation and DC shock were applied in the 
course of 10 minutes the survival rate is up to $2 \% .{ }^{6}$ Prehospital care for patients with STEMI should be improved by better regional network development in order to ensure rapid reperfusion therapy and $\mathrm{pPCl}$ available to as many patients as possible. ${ }^{1}$ According to modern recommendations, patients in whom $\mathrm{pPCl}$ is to be performed should receive dual antiplatelet therapy (Acetyl salicylic acid and P2Y12 inhibitor), so our patient in addition to Aspirin was loaded with a dose of $180 \mathrm{mg}$ Ticagrelor (non-thienopyridine antithrombotic drug with dual mechanism of action). Clopidogrel is indicated only if Ticagrelor or Prasugrel are unavailable or contraindicated. ${ }^{7}$ It has been shown earlier that patients after prolonged resuscitation can suffer more frequently from bleeding complications and in accordance with this experience, our patient was protected with Pantoprazole through a nasogastric probe. According to 2017 ESC Guidelines for the management of acute myocardial infarction in patients presenting with STEMI, for those presenting with out of hospital cardiac arrest in the course of STEMI, emergency coronary angiogram and $\mathrm{pPCl}$ is a therapeutic treatment of choice, and our patient was treated this way. Revascularization of the infarction artery with implantation of drug-releasing stents has an advantage over bare metal stents, especially when there is possibility of stent thrombosis. ${ }^{8}$ According to Guidelines, drug eluting stents were used in our patient. Results of the study by Belliard SA et al. clearly suggest that application of therapeutic hypothermia to haemodynamically stable patients with STEMI in the postresuscitated coma for not more then six hours from cardiac arrest can reduce brain ischemic damage. ${ }^{4}$ Based on current recommendations for managing STEMI patients and previous experiences, and after consulting a neurologist and performing endocranium CT (in order to exclude intracranial haemorrhage), therapeutic hypothermia was initiated in our patient. He did not have the following contraindications for implementation of therapeutic hypothermia: recent major surgical intervention, systemic infection-sepsis, coma of other etiology (drug poisoning, coma before resuscitation), current bleeding, isolated respiratory arrest preceded by coma. Recommended time for therapeutic hypothermia is 24 hours (from the cooling onset) and it was performed in our patient since he did not have any indication for premature interruption of hypothermia (signs of bleeding, severe bradycardia, arrhythmias, occurrence of Osborne waves in the ECG). Fast timely cardiopulmonary reanimation with application of therapeutic hypothermia significantly contributed to successful and complete recovery of our patient.

Conclusion: Fast and adequate measures of cardiopulmonal resuscitation in patients with STEMI complicated with out-of-hospital cardiac arrest are most important for their full recovery. $\mathrm{pPCl}$ is a treatment of choice for revascularization of infarction artery (especially in the first 120 minutes from chest pain). Prevention and better treatment of out-of-hospital cardiac arrest is of crucial importance for mortality reduction caused by coronary ischemic disease.

\section{Reference}

1. Ibanez B, James S., Agewall S, et al. 2017 ESC Guidelines for the management of acute myocardial infarction in patients presenting with ST-segment elevation; Eur Heart J. 2018 Jan 7;39(2):119-177

2. Larsen JM, Ravkilde J. Acute coronary angiography in patients resuscitated from out-of-hospital cardiac arrest: a systematic review and meta-analysis. Resuscitation 2012;83(12): 1427-1433.

3. Kern KB, Rahman O. Emergent percutaneous coronary intervention for resuscitated victims of out-of-hospital cardiac arrest. Catheter Cardiovasc Interv 2010; 75 (4):616-624

4. Belliard G, Catez E, Charron C, et al. Efficacy of therapeutic hypothermia after out-of-hospital cardiac arrest due to ventricular fibrillation. Resuscitation 2007; 75(2):252-259

5. Nikolaou NI, Welsford M, Beygui F. Part 5: Acute coronary syndromes: 2015 International Consensus on Cardiopulmonary Resuscitation and Emergency Cardiovascular Care Science with Treatment Recommendations. Resuscitation 2015; 95: e121-e146.

6. Steg PG, James SK, Atar D, et al. Guidelines for the management of acute myocardial infarction in patients presenting with STsegment elevation. Eur Heart J. 2012; 33(20):2569-619.

7. Wallentin L, Becker RC, Budaj A, et al. Ticagrelor versus clopidogrel in patients with acute coronary syndromes. N Engl J Med 2009; 361(11):1045-1057.

8. Kastrati A, Dibra A, Spaulding C, et al. Meta-analysis of randomized trials on drug-eluting stents vs. bare-metal stents in patients with acute myocardial infarction. Eur Heart 2007; 28(2):2706

\section{Sažetak}

\section{Savremeno lečenje akutnog infarkta miokarda sa ST elevacijom komplikovanog srčanim zastojem na terenu}

Ratko Lasica ${ }^{1}$, Mina Radosavljević-Radovanović1, Predrag Mitrović1, Ana Ušćumlić1, Igor Mrdović1, Milan Nedeljković ${ }^{2}$,Branislav Stefanović, ${ }^{1}$ Vladimir Zobenica ${ }^{1}$, Milika Ašanin $^{1}$

${ }^{1}$ Urgentna kardiologija, Klinički centar Srbije, Beograd, Srbija, ${ }^{2}$ Klinika za kardiologiju, Klinički centar Srbije, Beograd, Srbija

Uvod: Najčešći uzrok mortaliteta u akutnom infarktu miokarda sa ST elevacijom su maligni poremećaji srčanog ritma koji se uglavnom javljaju u prva četiri časa infarkta miokarda. Incidenca ventrikularne fibrilacije je najveća u ranoj fazi infarkta pa se naprasne srčane smrti najčešće dešavaju u vanbolničkim uslovima.

Prikaz bolesnika: U radu je prikazan bolesnik kod koga je prva manifestacija koronarne bolesti bio infarkt miokarda sa ST elevacijom komplikovan ranom ventrikularnom fibrilacijom. Brzim merama kardiopulmonalne reanimacije uspostavljena je srčana radnja. Bolesniku je učinjena primarna perkutana intervencija u toku koje je revaskularizovana infarktna arterija. Zbog održavanja postreanimacione kome bolesniku su primenjene mere terapijske hipotermije u cilju redukcije ishemijskog oštećenja mozga.

Zaključak: Bolje lečenje srčanog zastoja u vanbolničkim uslovima i brža revaskularizacija infarktne arterije su od ključnog značaja za redukciju mortaliteta u akutnom infarktu miokarda.

Ključne reči: akutni infarkt miokarda, srčani zastoj, savremeno lečenje 